\title{
STUDIES ON CERTAIN ASPECTS OF BEHAVIOUR IN THE BLIND CATFISH Horaglanis krishnai MENON
}

\author{
Anna MERCY, T.V*, N.K. PILLAI \& N.K. BALASUBRAMANIAN**
}

\begin{abstract}
Horaglanis krishnai is a blind catfish inhabiting the dug-out wells at Kottayam, Kerala. This fish has great zoogeographical importance as a similar blind clariid, Uegitglanis zammaroni is found only in the artesian wells of the former Italian Somaliland. Studies on certain behavioural aspects of the fish in captive conditions showed that, this fish even though is blind, exhibited a high degree of thigmotactism. Locomotion, comfort behaviour, feeding and light sensitivity of the fish were studied under laboratory conditions. Though the fish is totally blind and histological study did not reveal the presence of any light sensitive structures, the fish is found to be sensitive to light stimulus. It is a predator. Under laboratory conditions it unerringly snapped up food organisms. This is obviously facilitated by the high degree of development of the tactile and olfactory sense organs.
\end{abstract}

This study form part of the Ph.D thesis of the first author

Keywords: horaglanis krishnai, cave fishes, behaviour.

\section{Introduction}

The study of comparative behaviour in animals has now developed to such an extent that it can be said to have grown beyond the confines of biology. In the narrow sense, behaviour is the sum total of what an animal does or "the whole complex of observable or measurable, recordable activities of the living animal"(Verplanc, 1957). During the last two decades fish behaviour has been studied fairly extensively by field observations and under laboratory conditions (Breder, 1934, '35, '36; Noble and Curtis 1939; Greenberg 1947; Aroson 1945; Nymon 1953; Tinbergen, 1951, 53; Keenleyside 1955; Clarke 1970 and Kortmulder 1972).

Horaglanis krishnai is a blind clariid inhabiting the dug-out wells of Kottayam, Kerala State, India. Cavefish's attracted the attention of ichthyologists only comparatively recently. Till date, 32 species of fishes have been recorded from caves, artesian wells and subterranean waters. The discovery of the new blind clariid fish from

\footnotetext{
*Associate Professor, College of Fisheries, Panangad, P.O. Cochin 682506

** Professor, Dept. of Aquatic Biology \& Fisheries, University of Kerala, Trivandrum
} 
Kerala, Horaglanis krishnai Menon and the occurrence of a similar blind clariid fish, Uegitglanis zammaroni Gienferrai from Italian Somaliland have raised points of great zoogeographical interest. Our information about these two forms is, by no means adequate. Breder and Gresser (1941) made extensive studies on the blind characins. But no information is available on the behaviour of $H$. krishnai in captivity. Horaglanis krishnai has a peculiar habitat and hence only certain aspects of its behaviour could be investigated.

\section{MATERIALS AND METHODS}

Horaglanis krishnai occurs at the bottom of the dugout wells at Kottayam, (Lat. $8^{\circ} 4^{\prime} \mathrm{N}$ and $10^{\circ} 21^{\prime} \mathrm{N}$; Longitude $76^{\circ} 13^{\prime} \mathrm{E}$ and $\left.77^{\circ} 38^{\prime} \mathrm{E}\right)$ Kerala, South India. Specimens of H.krishnai were collected from the dug-out wells at Kottayam. As the fishes invariably rest on the bottom they could be collected only by draining the wells.This is a tedious and time-consuming exercise. Because of this difficulty, collections were made mostly during the summer (January to April), as the water level in the wells is low then. The wells were drained by drawing water out with buckets. During the rainy season (June to September) the water level is high and hence the wells can be drained only by pumping water out using an electric motor.

Whatever method is employed the wells can never be completely emptied as water will be gushing in through springs. Hence as soon as the bottom mud becomes visible, one of the workers would enter the well and vigorously agitate the small quantity of water present. The bottom sediments along with the water will be sent up in buckets in a semifluid state and emptied at a suitable place near the well. As the fishes are pink in colour and move about vigorously in the mud. Then they can be easily picked up and tranferred to a vessel containing clear well-water. The maximum number of fishes I could collect from one well was fifteen. This may be because it is virtually impossible to drain these wells completely.

The fishes were tranferred to polythene bags filled with water saturated with oxygen and transported to the laboratory at Trivandrum, $150 \mathrm{~km}$ away. The fishes invariably reached the laboratory, apparently in good condition, but during the course of two or three days, started dying. Hence, as a trial, subsequent collections of fishes were kept in aquarium tanks filled with well-water and having a bottom of silt transported from Kottayam along with the fishes. This appears to provide a natural environment. Mortality was considerably lower. The food given was mainly Chironomus larvae. The aquaria holding the fishes were kept in semi-dark place. I succeeded in keeping a few fishes healthy under these conditions for nearly two years. However, handling 
these fishes for experimental purpose was found to result in mortality of at least a few fishes. For behavioral studies, only fishes well-acclimatised to the laboratory conditions were used. The temperature of the water ranged between $27^{\circ}$ and $28^{\circ} \mathrm{C}$. Water was replenished to compensate for the loss by evaporation.

For all experiments, glass aquaria of size $60 \times 25 \times 25 \mathrm{~cm}^{3}$ were used. Observations were generally made 3-4 times a day and all experiments were continued for more than 24 hours. Each experiment was duplicated and the average of the results (expressed as percentage) was calculated. The containers were kept in a secluded place where the fishes were subjected to least disturbance. Feeding the fish and changing the water were done invariably at 5 P.M. and after that no readings were taken on that day.

\section{RESULTS}

The following aspects of the general behaviour of the fish were studied.

1. Locomotion

2. Comfort behaviour

3. Feeding

4. Light sensitivity

\section{Locomotion}

The locomotion of H. krishnai is comparable to that of other clariid fishes. It can be described as serpentine, anguilliform, or eel-like. The undulating movement of the body is primarily in the horizontal plane. Vertical upward or downward movements are very rare. As the fish moves forwards the tail is wagged providing the initial momentum. Transverse waves of contraction of the myomers travel from the anterior to the posterior end. The amplitude of these waves of contraction increases sharply where the trunk approaches the tail.

Observations under laboratory conditions, obviously somewhat unnatural, showed that these blind fishes perform a variety of movements. When they are first introduced into the tank, or in the presence of light, they swim about continuously; some sort of aimless wandering. Once the fishes get acclimatised to the artificial conditions in the tanks or when they are provided with some sort of shade, they often remain quiescent. At such times they swim away only if disturbed in one way or another or when they are engaged in taking food. 


\section{Comfort behaviour.}

As shown by Schiche (1921), catfishes in general, are strongly thigmotactic. $H$. krishnai, in spite of its peculiar habitat, is no exception. They invariably rest, with as many points of the body as possible in contact with the substratum. H. krishnai virtually lies on the bottom. This habit appears to have played an important part in developing a tendency to aggregate. These fishes appear to be eager to collect together in some shade, lie beneath leaves or stones or among pebbles. When hurdled together like that, they darted away in all directions if suddenly disturbed.

Formation of aggregations can be easily observed by making a group of fishes disperse by disturbing them. In 10-15 minutes after the disturbance, two or three individuals slowly approach the original site or another suitable site nearby. Individual fishes swim about at random and sooner or later manage to join their companions. Almost all the fishes come together in about an hour. The struggle to occupy the original site is so irresistible that late comers wriggle into the meager space available among those that remain in a bunch. Even after this, there are constant adjustments by individuals to such an extent that the members of an aggregation are never at complete rest.The aggregations are always formed beneath a stone, a leaf or some such hiding place. The least disturbance would make them scatter. But soon the above procedure will be repeated. Thigmotactic behaviour of a high degree is evident in this fish.

\section{Feeding}

The examination of the stomach contents of specimens soon after they were collected from the wells revealed the presence of only insects, insect larvae or their severed parts. Diptera and Coleoptera predominated.

Fishes kept in aquaria were given Chironomous larvae and Tubifex worms. Though a few fishes occasionally ate bites of tubifex worms, generally they did not relish them. On the other hand, when Chironomus larvae were placed near the place where they lay hiding, they invariably pounced on the prey.

As soon as the prey comes near the fishes hiding under the cover, and provided it is within striking distance, the fish partially emerges from hiding, seizes the prey in its mouth and retreats into the hide. Under laboratory conditions they were never seen feeding on dead matter or detritus. The jaws of H. krishnai are provided with several rows of incurved sharp teeth which help in holding the prey firmly preventing its escape. The prey is caught and taken in whole. H. krishnai can hence be described as a predator though a small edition of it. In spite of being blind the fish unerringly 
catches food and I have never seen any fish failing to do this. Obviously both olfactory and tactile senses help in this.

\section{Light sensitivity}

As already stated, H. krishnai shows a strong tendency to hide under stones, leaves etc. Whenever a beam of light is directed on to them, they move away from the beam of light and gather at the darkest portions of the aquarium. When they were placed in a glass tank with half of its sides shaded by pasting black paper, they always collect at this portion. They never go to the lighted area. Every fish shows this preference. No matter from which direction the light come, they swim en masse to the darkest part. The fishes are strongly photonegative.

\section{Other behavioral aspects}

A series of simple experiments were conducted to study the behaviour of $\mathrm{H}$. krishnai. Though these experiments were conducted wholly under artificial conditions it can be assumed that the results are, to a large extent, similar to those under natural conditions. It may be pointed out that this fish cannot be observed under natural conditions as it inhabits subterranean waters. The behaviour of the fish in an aquarium, with different kinds of substrate, and in relation to phototropism was investigated.

\section{Behaviour in an aquarium}

An aquarium $60 \times 25 \times 25 \mathrm{~cm}^{3}$ was set up with a bottom of river sand to a height of $4 \mathrm{~cm}$ and water column $20 \mathrm{~cm}$. Aquatic plants were planted irregularly in the bottom sand. Four large, nearly spherical, stones of identical size were placed on the sand bed, equidistant from one another and from the sides of the tank so that all the stones received the same degree of illumination. A few fishes were introduced into the centre of the aquarium from a small container, which was placed previously in the aquarium. The fishes were released by opening the container with the help of a stringarrangement operated from a distance. As soon as the fishes were released, they swarm all over the tank and remained scattered on the bottom at random. A few hid themselves amidst the weeds while others lay fully exposed. But gradually, during the course of an hour, every fish was found beneath the stones.

From the next day onwards, the frequencies of behaviour in this habitat were observed at definite intervals. The percentage of frequency in preferred sites is given 
in Table 1 .The results definitely showed that $H$. krishnai preferred to remain hiding under the stones. Moreover, even when more than one identical stones were available the fishes congregated under a single stone showing a pronounced gregarious tendency. When disturbed, the fishes scattered and quite often grouped themselves

Tab. 1 - Preferential sites chosen by Horaglanis krishani in an aquarium tank

\begin{tabular}{|c|c|c|c|}
\hline \multirow{2}{*}{$\begin{array}{c}\text { Sl. No of } \\
\text { observations }\end{array}$} & \multicolumn{4}{|c|}{ *PERCENTAGE OF FISHES IN TANKS WITH } \\
\cline { 2 - 4 } & Plants & Stones & Sand \\
\hline 1 & $\mathbf{8}$ & $\mathbf{8 4}$ & $\mathbf{8}$ \\
\hline 2 & - & 100 & - \\
\hline 3 & - & 100 & - \\
\hline 4 & - & 100 & - \\
\hline 5 & - & 100 & - \\
\hline 6 & - & 100 & - \\
\hline 7 & - & 100 & - \\
\hline 8 & - & 100 & - \\
\hline 9 & - & 100 & - \\
\hline 10 & - & 100 & - \\
\hline 11 & - & 100 & \\
\hline
\end{tabular}

* average of three observations

under a different stone. The size of the stone, the actual position of the stone, or the actual distance between the stone and the site at which the fishes were released, had no significant effect on the behaviour of the fish. Hence it can be concluded that, subject to the availability of some sort of cover, the fishes exhibit a strong gregarious tendency and react socially to each other.

\section{Behaviour in an aquarium with different substrata}

To investigate whether the nature of the substratum influences the behaviour of the fishes, another experiment was conducted. The bottom of a glass aquarium was partitioned into five compartments with wooden strips, $4 \mathrm{~cm}$ in height. The five compartments were filled with mud, coarse river sand, gravel, pebbles and large stones respectively, to a height of $4 \mathrm{~cm}$ so that the bottom had an even surface flush with the partitions. It was ensured that the whole tank received the same intensity of illumination. Fishes were then introduced as in the previous experiment and left undisturbed for about an hour.

The number of fishes in each experiment was counted periodically during the succeeding four days. The percentage of the number of fishes which took shelter in the different compartments was then calculated. It can be seen from the data presented 
in Table 2 that the number of fishes which preferred a substratum of pebbles is significantly higher than that which selected the substratum of stones. Even when the positions of the different compartments were interchanged the results were the same. Thus the fishes showed a definite preference for a pebbly bottom.

Tab. 2 - Behaviour of Horaglanis krishnai in ralation to different types of substratum

\begin{tabular}{|c|r|r|r|r|c|}
\hline $\begin{array}{c}\text { Sl.No of } \\
\text { observations }\end{array}$ & \multicolumn{7}{|c|}{ *PERCENTAGE OF FISHES ON } \\
\hline & Sand & Gravel & Pebbles & Stones & Mud \\
\hline 1 & - & - & 75 & 25 & - \\
\hline 2 & - & - & 83 & 17 & - \\
\hline 3 & - & - & 83 & 17 & - \\
\hline 4 & - & - & 83 & 17 & - \\
\hline 5 & - & - & 83 & 17 & - \\
\hline 6 & - & - & 83 & 17 & - \\
\hline 7 & - & - & 83 & 17 & - \\
\hline 8 & - & - & 83 & 17 & - \\
\hline 9 & - & - & 83 & 17 & - \\
\hline 10 & - & - & 83 & 17 & - \\
\hline 11 & - & - & 83 & 17 & - \\
\hline 12 & - & - & 83 & 17 & - \\
\hline
\end{tabular}

*denoted by percentage occurrence of fish on different substrata.

\section{Behaviour in relation to phototropism}

How the fishes respond to the intensity of illumination was studied in a third experiment. For this, a glass aquarium with a bottom of fine river sand was set up. Half the area of the sides of the tank was covered with black paper. The fishes were then introduced as before. After 24 hours the positions occupied by the fishes were recorded. Except for occasional sojourns into the illuminated area the fishes remained in the shaded area. Illumination has a strong influence on the behaviour of the fish. They are negatively phototropic.

\section{Correlation between blindness and general behaviour}

To understand the effect of the absence of eyes on the general behaviour of the fish, the following experiment was conducted which is mainly based on that of Breder (1941). Tanks of size $60 \times 25 \times 25 \mathrm{~cm}^{3}$, having an illuminated part and a shaded part were set up. The tanks were arranged in such a way that one half of the area was illuminated with a 60 watt bulb placed $3 \mathrm{ft}$. away and the other half was shaded with 
black cover placed close to the water surface. The idea was that by recording the positions of the fishes at definite intervals their response to illumination could be studied in a quantitative manner. In the case of a randomly wandering fish the number of observations obtained over a given area on the bottom should then be directly proportional to the whole area, if no preference was evident.

Tanks of the above mentioned size were half filled with water. One half of the tank was covered and the other was exposed. The entire side was covered with black paper. Fishes were then introduced. The position of the fish in the illuminated half was noted at five seconds interval. The illuminated area was changed and observations were continued to eliminate extraneous influences if any. However, the fishes appeared to be influenced solely by illumination in taking up any particular position. The experiment was repeated with 2,4,5,6, and 7 fishes at a time and each experiment was repeated six times. The details of the experiments are tabulated in (Table 3 ). The results were statistically analysed.

\section{Analysis and Interpretation}

The numbers of observations in each experiment with light and dark regions were pooled together. 't' test was applied to find out whether the number in the light/dark region deviated significantly from half or not. The test was applied to observations on one side only as this would apply to the other half also. Denoting $\mathrm{P}_{1}=$ proportion of observations in the dark region to the total and $\mathrm{P}=1 / 2$, then ' $\mathrm{t}$ ' will be given by

$$
\mathrm{t}=\frac{\mathrm{P}_{1}-\mathrm{P}}{\sqrt{1 / 2 \times 1 / 2 \times 1 / n}}
$$

where ' $n$ ' is the total number of observations in the light and dark regions. ' $t$ ' value greater than 2.0 would enable us to conclude that the proportion observed differed significantly from $1 / 2$, indicating a definite preference to one of the two regions. The ' $t$ ' value were calculated and are given in Table 4 which shows that the first two halves are not significant as they are less than 2.0. All the other values are greater than 2.0 and are significant. The proportion observed in the dark region is (Table 4) greater the light. This clearly shows that the fish definitely prefers the dark region. On the other hand, when only one or two fishes were introduced at a time, no pronounced preference, either for the dark or for the light portion, was evident, presumably because the fishes continued to move in a random fashion. When a larger number was introduced they formed a group which en masse showed pronounced aversion for direct illumination.To compare the proportions observed, when the number 
Tab. 3 - The results of the experiment conducted to study the response of the fish to light

\begin{tabular}{|c|c|c|c|c|c|}
\hline No of Expts. & No. of fish & Total observations & Ob.in light & Ob.in dark & Darkness area \\
\hline 1 & 1 & 100 & 60 & 49 & $50 \%$ \\
\hline 2 & 1 & 88 & 52 & 36 & $50 \%$ \\
\hline 3 & 1 & 133 & 59 & 74 & $50 \%$ \\
\hline 4 & 1 & 135 & 53 & 82 & $50 \%$ \\
\hline 5 & 1 & 100 & 50 & 50 & $50 \%$ \\
\hline 6 & 1 & 111 & 50 & 61 & $50 \%$ \\
\hline 1 & 2 & 121 & 68 & 53 & $50 \%$ \\
\hline 2 & 2 & 112 & 50 & 62 & $50 \%$ \\
\hline 3 & 2 & 115 & 45 & 70 & $50 \%$ \\
\hline 4 & 2 & 100 & 35 & 65 & $50 \%$ \\
\hline 5 & 2 & 107 & 55 & 52 & $50 \%$ \\
\hline 6 & 2 & 166 & 80 & 86 & $50 \%$ \\
\hline 1 & 4 & 224 & 31 & 193 & $50 \%$ \\
\hline 2 & 4 & 231 & 5 & 226 & $50 \%$ \\
\hline 3 & 4 & 348 & 37 & $3 \hat{114}$ & $50 \%$ \\
\hline 4 & 4 & 271 & 79 & 199 & $50 \%$ \\
\hline 5 & 4 & 202 & 30 & 182 & $50 \%$ \\
\hline 6 & 4 & 200 & 17 & 183 & $50 \%$ \\
\hline 1 & 5 & 100 & 22 & 78 & $50 \%$ \\
\hline 2 & 5 & 100 & 4 & 96 & $50 \%$ \\
\hline 3 & 5 & 100 & 1 & 99 & $50 \%$ \\
\hline 4 & 5 & 100 & 0 & 100 & $50 \%$ \\
\hline 5 & 5 & 100 & 0 & 100 & $50 \%$ \\
\hline 6 & 5 & 100 & 2 & 98 & $50 \%$ \\
\hline 1 & 6 & 100 & 0 & 100 & $50 \%$ \\
\hline 2 & 6 & 100 & 3 & 97 & $50 \%$ \\
\hline 3 & 6 & 100 & 5 & 95 & $50 \%$ \\
\hline 4 & 6 & 100 & 0 & 100 & $50 \%$ \\
\hline 5 & 6 & 100 & 1 & 99 & $50 \%$ \\
\hline 6 & 6 & 100 & 0 & 100 & $50 \%$ \\
\hline 1 & 7 & 100 & 0 & 100 & $50 \%$ \\
\hline 2 & 7 & 100 & 0 & 100 & $50 \%$ \\
\hline 3 & 7 & 100 & 0 & 100 & $50 \%$ \\
\hline 4 & 7 & 100 & 0 & 100 & $50 \%$ \\
\hline 5 & 7 & 100 & 0 & 100 & $50 \%$ \\
\hline 6 & 7 & 100 & 0 & 100 & $50 \%$ \\
\hline 1 & 8 & 100 & 0 & 100 & $50 \%$ \\
\hline 2 & 8 & 100 & 0 & 100 & $50 \%$ \\
\hline 3 & 8 & 100 & 0 & 100 & $50 \%$ \\
\hline 4 & 8 & 100 & 0 & 100 & $50 \%$ \\
\hline 5 & 8 & 100 & 0 & 100 & $50 \%$ \\
\hline 6 & 8 & 100 & 0 & 100 & $50 \%$ \\
\hline
\end{tabular}


Tab. 4 - ' $t$ ' values comapring proportion observed in the dark area for significance from 0.5 .

\begin{tabular}{|c|c|c|c|c|l|}
\hline $\begin{array}{l}\text { No. } \\
\text { of } \\
\text { Expts. }\end{array}$ & $\begin{array}{c}\text { No. of fish } \\
\text { examined }\end{array}$ & Proportion & 't' values & Inference & Results \\
\hline 1 & 1 & 0.5207 & 1.0402 & $\begin{array}{c}\text { Not significant } \\
\mathrm{P}<0.25\end{array}$ & $\begin{array}{l}\text { Proportion observed did not } \\
\text { significantly differ from } 0.5\end{array}$ \\
\hline 2 & 2 & 0.5247 & 1.3646 & $\begin{array}{c}\text { Not significant } \\
\mathrm{P}<0.25\end{array}$ & $\begin{array}{l}\text { Proportion observed did not } \\
\text { significantly differ from } 0.5\end{array}$ \\
\hline 3 & 4 & 0.8787 & 29.1327 & $\begin{array}{c}\text { Significant } \\
\mathrm{P}<.01\end{array}$ & $\begin{array}{l}\text { Proportion observed } \\
\text { significantly differ from } 0.5\end{array}$ \\
\hline 4 & 5 & 0.9525 & 25.5640 & $\begin{array}{c}\text { Significant } \\
\mathrm{P}<.01\end{array}$ & $\begin{array}{l}\text { Proportion observed } \\
\text { significantly differ from } 0.5\end{array}$ \\
\hline 5 & 6 & 0.9848 & 27.3126 & $\begin{array}{c}\text { Significant } \\
\mathrm{P}<.01\end{array}$ & $\begin{array}{l}\text { Proportion observed } \\
\text { significantly differ from } 0.5\end{array}$ \\
\hline 6 & 7 & 1.0000 & 28.2486 & $\begin{array}{c}\text { Significant } \\
\mathrm{P}<.01\end{array}$ & $\begin{array}{l}\text { Proportion observed } \\
\text { significantly differ from } 0.5\end{array}$ \\
\hline 7 & 8 & 1.0000 & 28.2486 & $\begin{array}{c}\text { Significant } \\
\mathrm{P}<.01\end{array}$ & $\begin{array}{l}\text { Proportion observed } \\
\text { significantly differ from } 0.5\end{array}$ \\
\hline
\end{tabular}

of fish is increased, 't' will be given by

$$
\mathrm{t}=\frac{\mathrm{P}_{1}-\mathrm{P}_{2}}{\sqrt{\mathrm{Pq}\left(\mathrm{n}_{1}+\mathrm{n}_{2}\right) / \mathrm{n}_{1} \times \mathrm{n}_{2}}}
$$

Where, $P=\frac{n_{1} p_{1}+n_{2} p_{2}}{n_{1}+n_{2}}$

$\mathrm{q}=1-\mathrm{P}$ and $\mathrm{P}_{1}$ is the proportion observed in the experiment and $\mathrm{P}_{2}$ in that of another; $n_{1}$ and $n_{2}$ are the total number of observations in two experiments respectively; ' $t$ ' values calculated for each experiment are given in table 5. These values show that when we compare the proportion between each experiment, all the values are significant. With the increase in the number of fishes there is a gradual increase in the proportion observed in the dark region Table 5, which reaches the highest level when seven fishes were used. This reveals that density of fishes has an apparently marked influence on its behaviour.

\section{DISCUSSION}

Though H.krishnai apparently lacks any organ capable of receiving visual stimuli, they do react to the presence of light. Breder and Gresser (1941) found that the blind characins are negatively phototropic. Breder and Nigrelli $(1935,1938)$ suggested that 
Tab. 5 - *' ' $t$ ' values for comparing the proportion observed in the dark region between experiments.

\begin{tabular}{|c|l|l|l|l|l|l|l|}
\hline $\begin{array}{c}\text { No.of } \\
\text { Expt. }\end{array}$ & 1 & 2 & 4 & 5 & 6 & 7 & 8 \\
\hline 1 & - & 3.8787 & 18.1068 & 19.0933 & 20.9964 & 22.0819 & 22.0819 \\
\hline 2 & - & - & 18.3087 & 19.2356 & 21.1182 & 22.1482 & 22.1482 \\
\hline 3. & - & - & - & 5.7209 & 8.6918 & 10.2623 & 10.2623 \\
\hline 4 & - & - & - & - & 3.6957 & 6.2418 & 6.2418 \\
\hline 5 & - & - & - & - & - & 3.4917 & 3.4917 \\
\hline 6 & - & - & - & - & - & - & $0^{*}$ \\
\hline
\end{tabular}

* not significant All other values are significant at $1 \%$ level $(P<0.01)$

schooling is dependent solely on vision. This appears to be the reason why the blind characins do not show a schooling tendency as suggested by Breder and Gresser (1941). As already stated, H.krishnai does not appear to have any light receptor organ but the fish shows a gregarious tendency which is akin to schooling. This must, therefore, be induced by some factor other than the sense of sight.

The life of fishes is influenced by several kinds of olfactory stimulants: both repellants and attractants (von frisch,1941). It has been suggested that attractant odour, more than vision, helps to keep members of cyprinid species together. Hemmings (1966) observed that attractant odour plays an important role in forming and maintaining schools of fish, especially during night. Byrant and Atema (1980) while experimenting on Ictalurus nebulosus found that the body odour has decisive influence in keeping members together. They also found that the odour is dependent on the kind of food taken. Groups of individuals, feeding on different kinds of food, fail to keep together at least for a definite interval of time. In the present study, the schooling of $H$ krishnai might be influenced by the high development of olfactory and tactile sense organs.

\section{References}

ARONSON,L. R. 1945 Influence of the stimuli provided by the male cichlid fish Tilapia macrocephala on the spawning frequency of the female. Physiol.Zool., 18: 403-423. 
BREDER, C.M. Jr. 1934 An experimental study of the reproductive habits and life history of the cichlid fish, Acquidens latifrens (Steindachner). Zoologica,N.Y., 18: 1-42

BREDER, C. M. Jr 1935 The reproductive habits of the common catfish Ameiurus nebulosus (Le Sueur) with a discussion of their significance in ontogeny and phylogeny. Zoologica, N.Y., 19: 143-186.

BREDER, C. M. Jr 1936 The reproductive habits of the North American sunfishes, Centrarchidae. Zoologica, N.Y., 21: 1-48

BREDER, C. M. Jr. \& E. B.GRESSER 1941 Correlation between structural eye defects and behaviour in the Mexican blind characin. Zoologica, N.Y., 26: 123-131

BREDER, C.M. Jr. \& R.F. NIGRELLI 1935. The influence of temperature and other factors of the winter aggregations of the sunfish, Lepomis auratus with critical remarks on the social behaviour of fishes. Ecology, 16: 1-47

BREDER,C .M. Jr. \& R. F. NIGRELLI 1938. The significance of differential locomotor activ ity as an index of mass physiology of fishes. Zoologica, N.Y., 23: 1-29

BYRANT, B \& J. ATEMA 1980 Chemoreception in catfish: effects of diet on behaviour and body odour. Biol. Bull., 157: 360(Abstract).

CLARKE,T.A. 1970 Territorial behaviour and population dynamics of a pomacentrid fish, the Garibaldi, Hypsypops rubicunda. Ecol.Monogr., 40: 189-212.

GREENBERG, B. 1947 Some relations between territory, social hierarchy and leadership in the green sunfish (Lepomis canellas). Physiol.Zool. 20: 267-272

HEMMINGS,C,C. 1966 Olfaction and vision in fish schooling. J. Expt.Biol.,45: 449-464.

KEENLEYSIDE,M.H.A. 1955 Some aspects of the schooling behaviour of fish. Behaviour, 8: $183-186$

KORTMULDER, K. 1972 A comparative study in colour patterns and behaviour in seven Asiatic Barbus species (Cyprinidae, Ostariophysii, Osteichthys). A progress report. Behaviour, Leiden, E.J. Brill

NOBLE ,G. K. \& B. CURTIS. 1939 The social behaviour of the jewel fish Hemichromis bimaculatus Gill. Bull.Am. Museum. Nat.Hist., 76: 1-46.

NYMAN, K. J. 1953 Observations on the behaviour of Gobius microps. Acta Soc. Fauna Flora fenn., 69: 1-11.

SCHICHE, O. E. 1921 Reflex biologische studien an Boden-fischen. 1. Beobachtungen an Amiurus nebulosus. Zool. Jaheb (Zool), 38: 49-112

TINBERGEN,N. 1951 “The study of Instincts”. Oxford Univ. Press, N.Y.

TINBERGEN,N. 1953 "Social Behaviour in Animals" Methuen, London

VERPLANC, W.S. 1957 A glossary of some terms used in the objective science of behaviour. Psychol.Rev., 64: 1-42.

VON FRISCH, K. 1941 Die Bideutung des Geruchassinnes in Leben der Fische. Naturwissenschaften, 29: 321-333 